Prepared in cooperation with the Indiana Office of Community and Rural Affairs

\title{
Flood-Inundation Maps for the Big Blue River at Shelbyville, Indiana
}

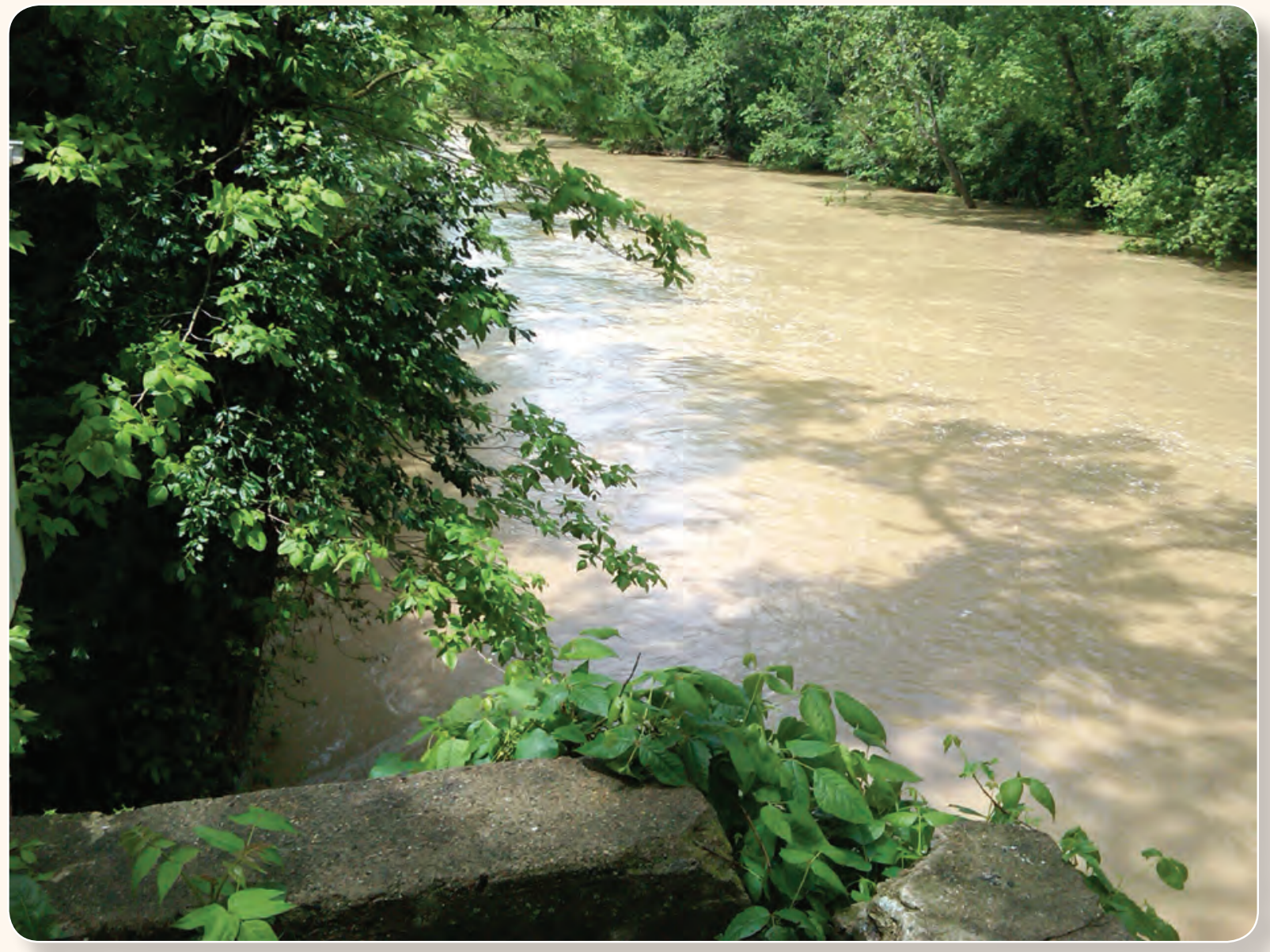

Scientific Investigations Report 2016-5166 
Cover photograph: Big Blue River at Shelbyville. It was taken May 5, 2011 by Lauren Burrous of the U.S. Geological Survey. 


\section{Flood-Inundation Maps for the Big Blue River at Shelbyville, Indiana}

By Kathleen K. Fowler

Prepared in cooperation with the Indiana Office of Community and Rural Affairs

Scientific Investigations Report 2016-5166 


\section{U.S. Department of the Interior SALLY JEWELL, Secretary}

\section{U.S. Geological Survey Suzette M. Kimball, Director}

\section{U.S. Geological Survey, Reston, Virginia: 2017}

For more information on the USGS - the Federal source for science about the Earth, its natural and living resources, natural hazards, and the environment-visit https://www.usgs.gov or call 1-888-ASK-USGS.

For an overview of USGS information products, including maps, imagery, and publications, visit https://store.usgs.gov/.

Any use of trade, firm, or product names is for descriptive purposes only and does not imply endorsement by the U.S. Government.

Although this information product, for the most part, is in the public domain, it also may contain copyrighted materials as noted in the text. Permission to reproduce copyrighted items must be secured from the copyright owner.

Suggested citation:

Fowler, K.K., 2017, Flood-inundation maps for the Big Blue River at Shelbyville, Indiana: U.S. Geological Survey Scientific Investigations Report 2016-5166, 11 p., https://doi.org/10.3133/sir20165166.

ISSN 2328-0328 (online) 


\section{Acknowledgments}

The author wishes to thank the U.S Geological Survey National Streamflow Information Program for cooperating in the funding for the operation and maintenance of the gage used for this study. Special thanks are given to the Indiana Office of Community and Rural Affairs for their cooperation in this study and to the National Weather Service for their continued support to the U.S. Geological Survey flood-inundation mapping initiative. 



\section{Contents}

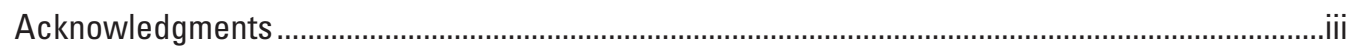

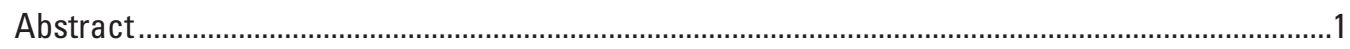

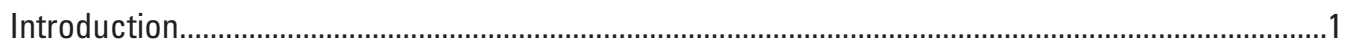

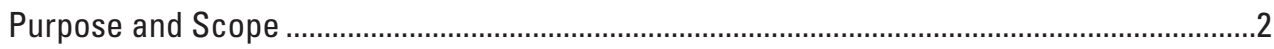

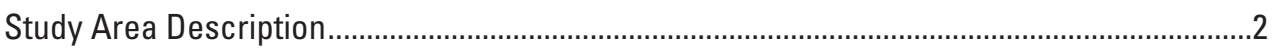

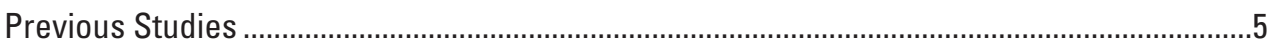

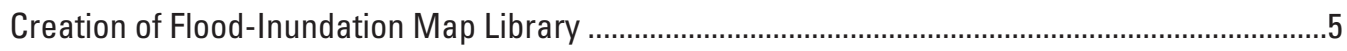

Computation of Water-Surface Profiles ...............................................................................

Hydrologic Data..................................................................................................

Topographic and Bathymetric Data .........................................................................

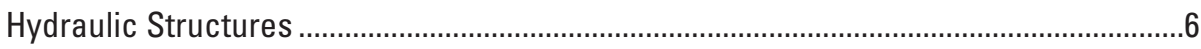

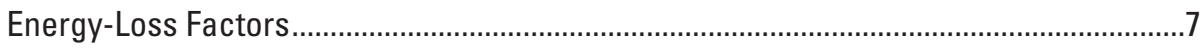

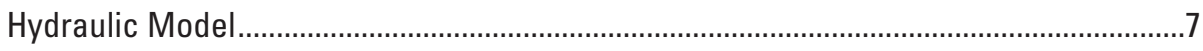

Development of Water-Surface Profiles.......................................................................

Development of Flood-Inundation Maps ...........................................................................

Flood-Inundation Map Delivery ..............................................................................

Disclaimer for Flood-Inundation Maps ..........................................................................8

Uncertainties and Limitations Regarding Use of Flood-Inundation Maps ........................8

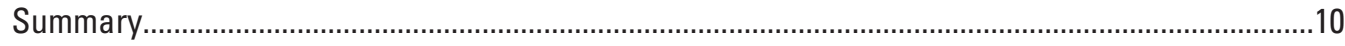

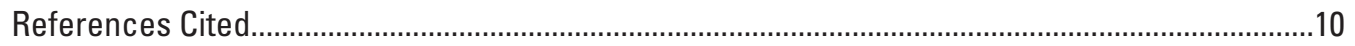

\section{Figures}

1. Map showing locations of study reach for the Big Blue River at Shelbyville, Indiana; U.S. Geological Survey streamgage 03361500; and National Weather Service forecast site SBVI3.

2 Map showing flood-inundation map for the Big Blue River at Shelbyville, Indiana, corresponding to a stage of 19.4 feet at the U.S. Geological Survey streamgage (station number 03361500).

\section{Tables}

1. U.S. Geological Survey streamgage information for the Big Blue River at Shelbyville, Indiana (station number 03361500)

2. Coordinated discharges for selected annual exceedance probabilities for the Big Blue River at Shelbyville, Indiana .

3. Estimated discharges for corresponding stages and water-surface elevations at selected locations used in the hydraulic model of the Big Blue River at Shelbyville, Indiana

4. Calibration of hydraulic model to target water-surface elevations at the U.S. Geological Survey streamgage on the Big Blue River at Shelbyville, Indiana (station number 03361500). 


\section{Conversion Factors}

U.S. customary units to International System of Units

\begin{tabular}{lcl}
\hline \multicolumn{1}{c}{ Multiply } & By & \multicolumn{1}{c}{ To obtain } \\
\hline foot $(\mathrm{ft})$ & Length & meter $(\mathrm{m})$ \\
mile $(\mathrm{mi})$ & 0.3048 & kilometer $(\mathrm{km})$ \\
\hline \multicolumn{3}{l}{ Area } \\
\hline square mile $\left(\mathrm{mi}^{2}\right)$ & 1.609 & square kilometer $\left(\mathrm{km}^{2}\right)$ \\
\hline & 2.590 & \\
\hline cubic foot per second $\left(\mathrm{ft}^{3} / \mathrm{s}\right)$ & Flow rate & cubic meter per second $\left(\mathrm{m}^{3} / \mathrm{s}\right)$ \\
\hline & 0.02832 & \\
\hline foot per mile $(\mathrm{ft} / \mathrm{mi})$ & Hydraulic gradient & meter per kilometer $(\mathrm{m} / \mathrm{km})$ \\
\hline
\end{tabular}




\title{
Flood-Inundation Maps for the Big Blue River at Shelbyville, Indiana
}

\author{
By Kathleen K. Fowler
}

\section{Abstract}

Digital flood-inundation maps for a 4.1-mile reach of the Big Blue River at Shelbyville, Indiana, were created by the U.S. Geological Survey (USGS) in cooperation with the Indiana Office of Community and Rural Affairs. The floodinundation maps, which can be accessed through the USGS Flood Inundation Mapping Science Web site at https://water. usgs.gov/osw/flood_inundation/, depict estimates of the areal extent and depth of flooding corresponding to selected water levels (stages) at the USGS streamgage on the Big Blue River at Shelbyville, Ind. (station number 03361500). Near-real-time stages at this streamgage may be obtained from the USGS National Water Information System at https://waterdata. usgs.gov/ or the National Weather Service (NWS) Advanced Hydrologic Prediction Service at https://water.weather.gov/ ahps/, which also forecasts flood hydrographs at this site (SBVI3).

Flood profiles were computed for the stream reach by means of a one-dimensional step-backwater model. The hydraulic model was calibrated by using the most current stage-discharge relation at the Big Blue River at Shelbyville, Ind., streamgage. The calibrated hydraulic model was then used to compute 12 water-surface profiles for flood stages referenced to the streamgage datum and ranging from 9.0 feet, or near bankfull, to 19.4 feet, the highest stage of the current stage-discharge rating curve. The simulated water-surface profiles were then combined with a Geographic Information System digital elevation model (derived from light detection and ranging [lidar] data having a 0.98 -foot vertical accuracy and 4.9-foot horizontal resolution) to delineate the area flooded at each water level.

The availability of these maps, along with Internet information regarding current stage from the USGS streamgage at the Big Blue River at Shelbyville, Ind., and forecasted stream stages from the NWS, will provide emergency management personnel and residents with information that is critical for flood response activities such as evacuations and road closures as well as for post-flood recovery efforts.

\section{Introduction}

The city of Shelbyville in Shelby County, Indiana, has an estimated population of 19,191 (U.S. Census Bureau, 2010). Shelbyville and the surrounding area have experienced flooding numerous times, most recently in 2005, 2011, and 2013. The majority of flood damages in the Shelbyville area have occurred along the Big Blue River in the northwest part of the city (Federal Emergency Management Agency, 2006) (fig. 1). During major flood events, there is extensive flooding along the left (south) bank of the Big Blue River as embankments are overtopped or circumvented. Businesses and residential property close to the river on both sides are also affected. As the stage rises, some local roads are impassable. In addition, agricultural lands surrounding the city have potential for flooding as embankments are overtopped. Flood plains along the river are moderately developed and contain a mix of residential, commercial, and agricultural areas.

Prior to this study, emergency responders in Shelbyville relied on several information sources to make decisions on how to best alert the public and mitigate flood damages. One source is the Federal Emergency Management Agency (FEMA) flood insurance study (FIS) for Shelby County (Federal Emergency Management Agency, 2006). A second source of information is the U.S. Geological Survey (USGS) streamgage, Big Blue River at Shelbyville, Ind. (03361500), from which current (U.S. Geological Survey, 2014c) and historical (U.S. Geological Survey, 2014e) water levels (stage) and discharges can be obtained. A third source is the National Weather Service (NWS) Advanced Hydrologic Prediction Service (AHPS) Web site for the streamgage, which issues forecasts of stage at the USGS streamgage (National Weather Service, 2014c).

Although the current stage at a USGS streamgage is particularly useful for residents in the immediate vicinity of a streamgage, it is of limited use to residents farther upstream or downstream because the water-surface elevation is not constant along the entire stream reach. Knowledge of a water level at a streamgage is difficult to translate into depth and areal extent of flooding at points distant from the streamgage. One way to address these informational gaps is to produce 
a library of flood-inundation maps that are referenced to the stages recorded at the USGS streamgage. By referring to the appropriate map, emergency responders can discern the severity of flooding (depth of water and areal extent); identify roads that are, or will soon be, flooded; and make plans for notification or evacuation of residents in harm's way for some distance upstream and downstream from the streamgage. In addition, the capability to visualize the potential extent of flooding has been shown to motivate residents to take precautions and heed warnings that they previously might have disregarded. In 2015-16, the USGS, in cooperation with the Indiana Office of Community and Rural Affairs, conducted a project to produce a library of flood-inundation maps for the Big Blue River at Shelbyville.

\section{Purpose and Scope}

This report describes the development of a series of estimated flood-inundation maps for the Big Blue River at Shelbyville and identifies where on the Internet the maps can be accessed and ancillary data (Geographic Information System [GIS] flood polygons and depth grids) can be downloaded. Internet users can select estimated inundation maps that correspond to (1) flood stages at streamgage 03361500 and (2) the NWS forecasted stages at the NWS site SBVI3. The scope of the study was limited to the Big Blue River reach extending 1.47 miles (mi) upstream and $2.63 \mathrm{mi}$ downstream from streamgage 03361500 at the State Road 9 bridge (fig. 1).

The flood-inundation maps were produced for flood levels referenced to the stage recorded at streamgage 03361500 (table 1); the streamgage is on the upstream side of the State Road 9 bridge. The maps cover a range in stage from 9 to 19.4 feet (ft). The 9-ft stage is approximately bankfull and is defined by the National Weather Service (2014b) as the "action stage" or that stage which, when reached by a rising stream, requires the NWS or a partner to take some type of mitigation action in preparation for possible significant hydrologic activity. The major flood stage, as determined by the NWS, is $18 \mathrm{ft}$. The 19.4-ft stage is the highest stage on the most recent stage-discharge rating curve number 42.0 (updated May 20, 2013). During a recent flood at Shelbyville on January 6,2005 , the stage was $18.43 \mathrm{ft}$, the highest recorded stage since 1913 (U.S. Geological Survey, 2014d).

\section{Study Area Description}

The Big Blue River near the city of Shelbyville is in central Indiana in the New Castle Till Plains and Drainageways physiographic section of the Central Till Plain Region (Gray, 2000). The drainage area is 314 square miles $\left(\mathrm{mi}^{2}\right)$ at the upstream end of the study reach, $421 \mathrm{mi}^{2}$ at streamgage 03361500 , and $423 \mathrm{mi}^{2}$ at the downstream end of the study reach (U.S. Geological Survey, 2014c, b). The headwaters originate in Henry County, Ind. (not shown), and the stream flows generally southwestward. As the river passes the northeast edge of the city, it is flowing to the southwest. Within the study reach, the Big Blue River has one significant tributary, the Little Blue River, which joins the river just upstream of the Noble Street bridge at the northeast side of Shelbyville.

Generally, the area has till plains of low relief crossed by many major tunnel-valleys (Gray, 2000), meltwater features from the last glaciation. The study reach is approximately $4.1 \mathrm{mi}$ long, has an average top-of-bank channel width of about $140 \mathrm{ft}$, and has an average channel slope of 0.0004 (2.27 feet per mile [ft/mi]). Much of the land contiguous to the study reach on the north side of the river is agricultural with some industry. The city of Shelbyville is on the south side of the river with rural homes and agriculture west of the city.

The population of Shelbyville has increased in recent years from 17,951 in 2000 to 19,191 in 2010 (U.S. Census Bureau, 2010). According to the U.S. Census Bureau (https:// www.census.gov), the city has a total area of $11.8 \mathrm{mi}^{2}$, of which $11.6 \mathrm{mi}^{2}$ are land and $0.2 \mathrm{mi}^{2}$ is water. The main channel and adjacent flood plain within the study reach have two major road crossings, State Road 9 and Noble Street, and one railroad crossing.

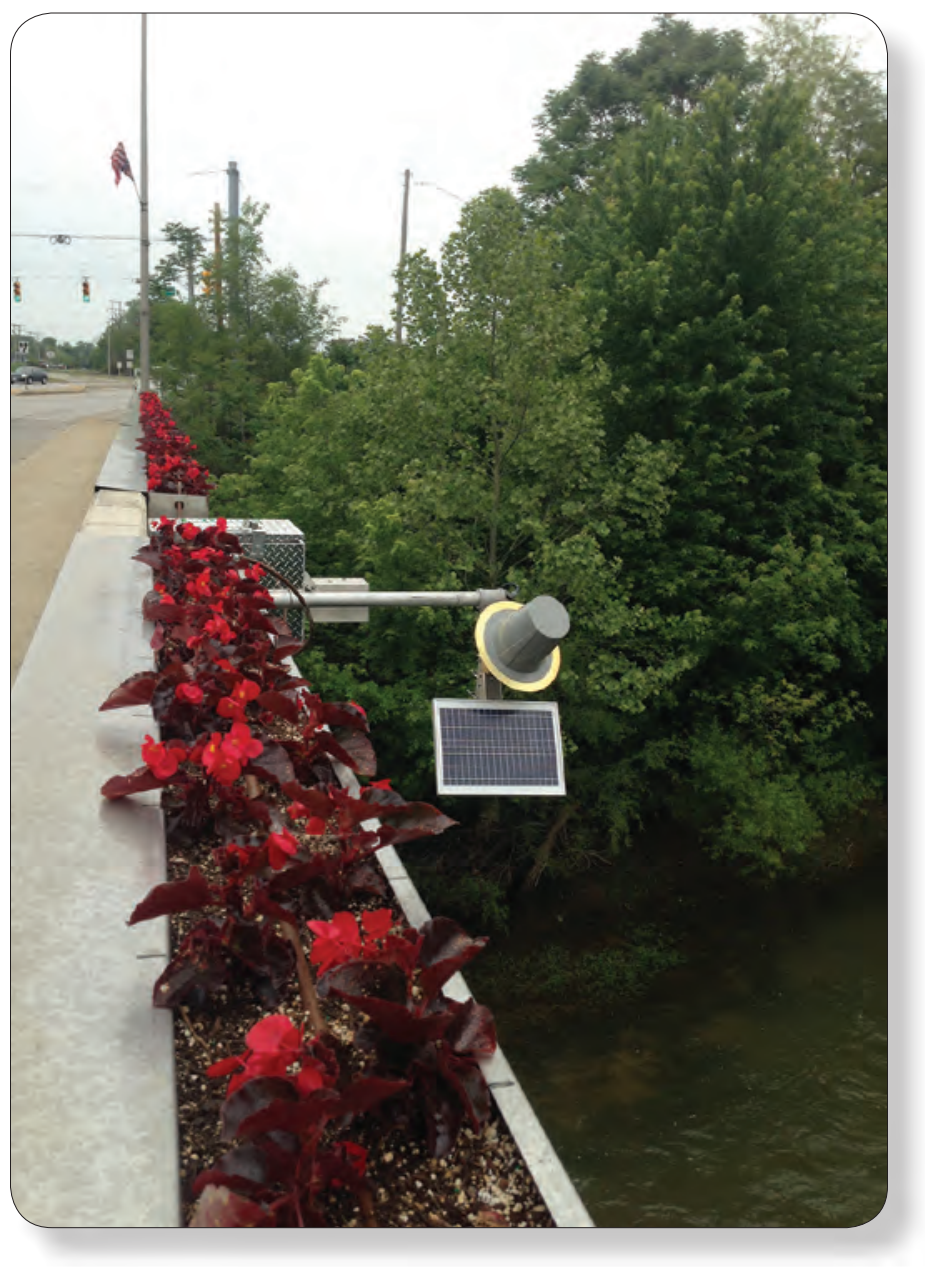

Photograph was provided by U.S. Geological Survey personnel 


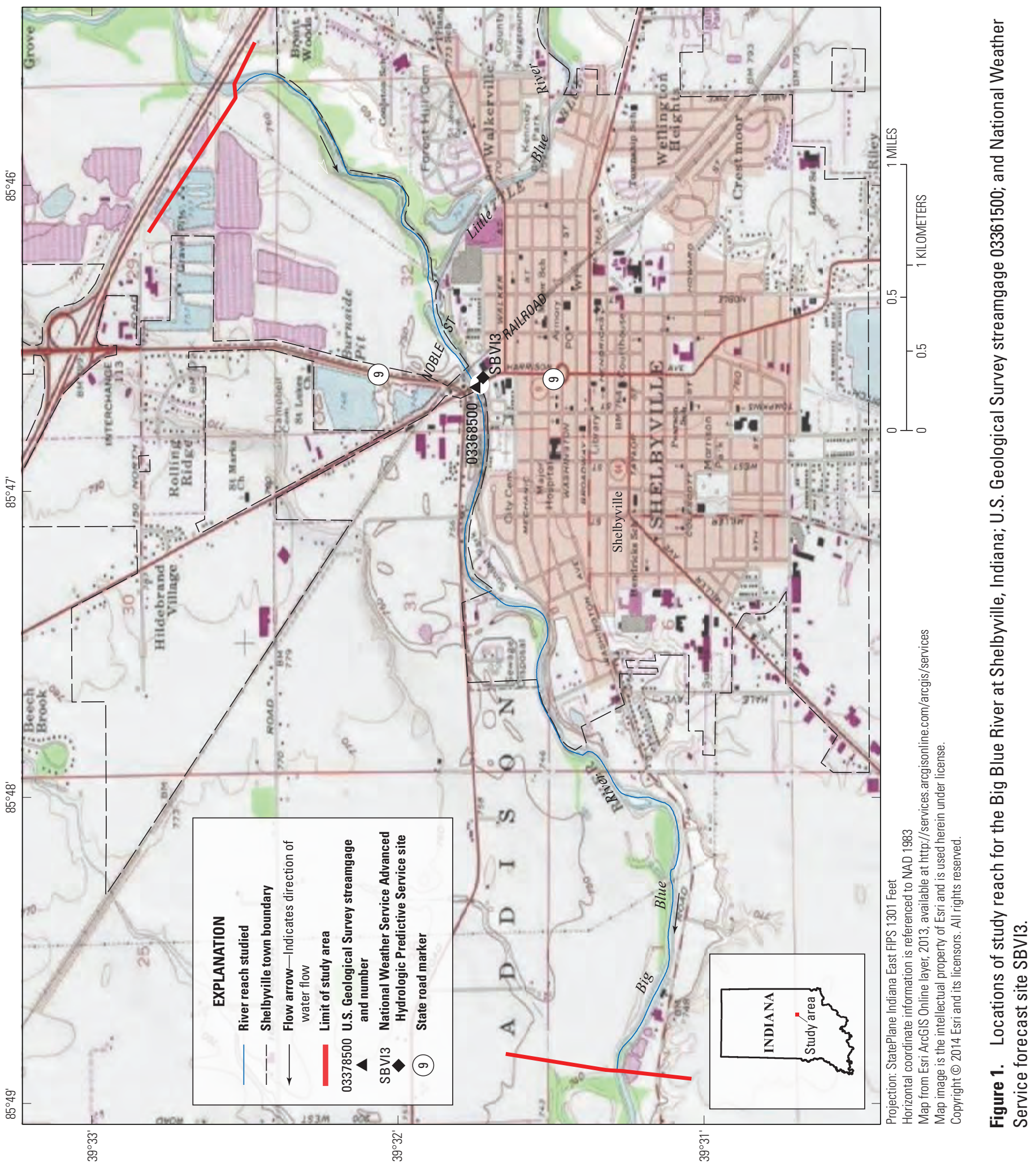



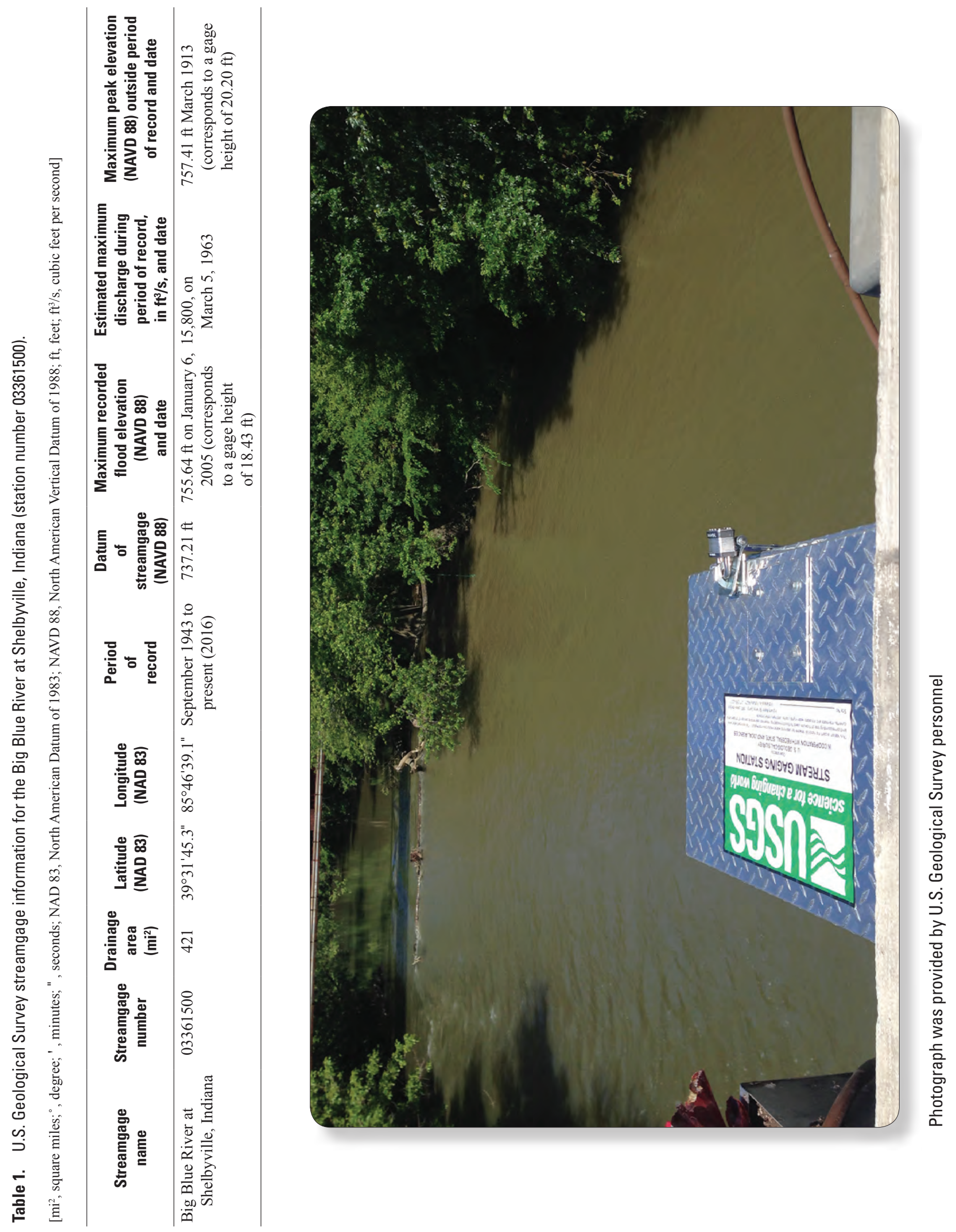


\section{Previous Studies}

The most recent FIS that provides information for the study area near the Big Blue River at Shelbyville is the Preliminary FIS for Shelby County (Federal Emergency Management Agency, 2006) and covers the geographic area of Shelby County, Ind., including the incorporated community of Shelbyville. The previously effective FIS for the City of Shelbyville is dated October 1, 1981 (Federal Emergency Management Agency, 1981). The hydrologic and hydraulic analyses for that study were performed by the U.S. Army Corps of Engineers, Louisville District, and Snell Environmental Group, Inc., for the Federal Insurance Administration under Contract No. H-4777 and was completed in May 1979. The new study (2006) provides analyses for approximate reaches of Shelby County.

The Indiana Department of Natural Resources (Indiana DNR) has produced Digital Flood Insurance Rate Maps (DFIRMs) that include the study area in Shelby County (Indiana Department of Natural Resources, 2004). These maps outline the special flood hazard areas around Shelbyville. In addition, the Indiana DNR, the USGS, the Natural Resources Conservation Service, and the U.S. Army Corps of Engineers have agreed to the discharge-frequency values for sites along many rivers in Indiana; the values are termed coordinated discharges and assure consistency among the State and Federal agencies that undertake streamflow studies (Indiana Department of Natural Resources, 2014). The coordinated discharges for the Big Blue River at Shelbyville were obtained from the USGS StreamStats Program for Indiana streams (U.S. Geological Survey, 2014b) and are listed in table 2.

Table 2. Coordinated discharges for selected annual exceedance probabilities for the Big Blue River at Shelbyville, Indiana.

$\left[\mathrm{mi}^{2}\right.$, square miles; $\mathrm{ft}^{3} / \mathrm{s}$, cubic feet per second; USGS, U.S. Geological Survey]

\begin{tabular}{|c|c|c|c|c|}
\hline \multirow[t]{2}{*}{$\begin{array}{l}\text { Location on } \\
\text { Big Blue River }\end{array}$} & \multirow{2}{*}{$\begin{array}{l}\text { Drainage } \\
\text { area } \\
\left(\mathrm{mi}^{2}\right)\end{array}$} & \multicolumn{3}{|c|}{$\begin{array}{l}\text { Coordinated discharges }\left(\mathrm{ft}^{3} / \mathrm{s}\right)^{1,2} \\
\text { for indicated annual exceed- } \\
\text { ance probabilities (in percent) }\end{array}$} \\
\hline & & 10 & 2 & 1 \\
\hline $\begin{array}{l}\text { At USGS } \\
\text { streamgage num- } \\
\text { ber } 03361500\end{array}$ & 421 & 12,800 & 17,700 & 20,000 \\
\hline
\end{tabular}

${ }^{1}$ Data from the StreamStats Program (U.S. Geological Survey, 2014d).

${ }^{2}$ Data from Indiana Department of Natural Resources coordinated discharges for the Big Blue River (modified) Shelbyville gage.

\section{Creation of Flood-Inundation Map Library}

The USGS has standardized the procedures for creating flood-inundation maps for flood-prone communities so that the process followed and products produced are similar regardless of which USGS office is responsible for the work (U.S. Geological Survey, 2014a). Tasks specific to development of the flood maps for Shelbyville, Ind., were (1) collection of topographic and bathymetric data for selected cross sections and geometric data for the State Road 9 bridge, the railroad bridge, and the Noble Street bridge; (2) estimation of energyloss factors (roughness coefficients) in the stream channel and flood plain and determination of steady-flow data; (3) computation of water-surface profiles using the U.S. Army Corps of Engineers' HEC-RAS computer program (U.S. Army Corps of Engineers, 2010); (4) production of estimated flood-inundation maps at various stream stages using the U.S. Army Corps of Engineers' HEC-GeoRAS computer program (U.S. Army Corps of Engineers, 2011) and a GIS (geographic information system); and (5) preparation of the maps, both as shapefile polygons that depict the areal extent of flood inundation and as depth grids that provide the depth of floodwaters, for display on a USGS flood-inundation mapping application.

\section{Computation of Water-Surface Profiles}

The water-surface profiles used to produce the 12 floodinundation maps in this study were simulated by using HECRAS, version 4.1.0 (U.S. Army Corps of Engineers, 2010). HEC-RAS is a one-dimensional step-backwater model for simulation of water-surface profiles with steady-state (gradually varied) or unsteady-state flow computation options. The HEC-RAS analysis for this study was done using the steadystate (gradually varied) flow computation option.

\section{Hydrologic Data}

The study reach consists of one streamgage 03361500 (fig. 1; table 1), which has been in operation since September 1943 and is colocated with the NWS AHPS site SBVI3. This streamgage has a continuous record of measured water level (stage) and computed streamflow. Stage is measured every 15 minutes, transmitted hourly by a satellite radio in the streamgage, and made available on the Internet through the USGS National Water Information System (NWIS; U.S. Geological Survey, 2014e). Stage data from this streamgage are referenced to a local datum but can be converted to watersurface elevations referenced to the North American Vertical Datum of 1988 (NAVD 88) by adding $737.21 \mathrm{ft}$. Continuous records of streamflow are computed from a stage-discharge relation, which has been developed for the streamgage, and are available through the USGS NWIS Web site. 
The steady-flow data necessary for the hydraulic model consisted of boundary conditions (normal depth) and peak-discharge information. The peak flows used in the model simulations (table 3) were taken from the current stage-discharge relation (USGS rating no. 42, effective March 9, 2010) for streamgage 03361500 and corresponded with the target stages. All computations used discharge values with known stages from actual streamflow measurements or the stage-discharge relation at the gage. One tributary, the Little Blue River, joins the Big Blue River within the 4.1-mi study reach. The drainage area of the Big Blue River above the confluence is $315 \mathrm{mi}^{2}$. The streamgage-derived discharges were adjusted, as necessary, to account for tributary inflow (table 3 ). These adjustments were estimated by calculating cubic feet per second per square mile (CFSM) that corresponded to the measured discharges at the Big Blue River gage. The CFSM is defined as the average number of cubic feet of water per second flowing from each square mile of area drained by a stream, assuming that the runoff is distributed uniformly in time and area.

Table 3. Estimated discharges for corresponding stages and water-surface elevations at selected locations used in the hydraulic model of the Big Blue River at Shelbyville, Indiana.

[NAVD 88, North American Vertical Datum of 1988; $\mathrm{ft}^{3} / \mathrm{s}$, cubic feet per second; USGS, U.S. Geological Survey]

\begin{tabular}{|c|c|c|c|}
\hline \multirow{2}{*}{$\begin{array}{c}\text { Stage of } \\
\text { water-surface } \\
\text { profile }^{1} \\
\text { (in feet) }\end{array}$} & \multirow[b]{2}{*}{$\begin{array}{c}\text { Water-surface } \\
\text { elevation } \\
\text { (in feet, NAVD } \\
\text { 88) }\end{array}$} & \multicolumn{2}{|c|}{$\begin{array}{l}\text { Estimated discharge }\left(\mathrm{ft}^{3} / \mathrm{s}\right) \\
\text { at indicated location }\end{array}$} \\
\hline & & $\begin{array}{l}\text { At upstream } \\
\text { end of study } \\
\text { reach }\end{array}$ & $\begin{array}{l}\text { Downstream } \\
\text { from conflu- } \\
\text { ence with Little } \\
\text { Blue River }\end{array}$ \\
\hline 9 & 746.21 & 1,900 & 2,540 \\
\hline 10 & 747.21 & 2,430 & 3,250 \\
\hline 11 & 748.21 & 3,020 & 4,030 \\
\hline 12 & 749.21 & 3,650 & 4,880 \\
\hline 13 & 750.21 & 4,350 & 5,810 \\
\hline 14 & 751.21 & 5,090 & 6,800 \\
\hline 15 & 752.21 & 5,880 & 7,860 \\
\hline 16 & 753.21 & 6,720 & 8,980 \\
\hline 17 & 754.21 & 7,930 & 10,600 \\
\hline 18 & 755.21 & 10,300 & 13,700 \\
\hline 19 & 756.21 & 13,000 & 17,400 \\
\hline 19.4 & 756.61 & 14,200 & 19,000 \\
\hline
\end{tabular}

${ }^{1}$ Water-surface profiles are increments of stage, referenced to the gage datum of the U.S. Geological Survey streamgage on the Big Blue River at Shelbyville, Indiana (station number 03361500).

${ }^{2}$ Discharge from U.S. Geological Survey rating number 42, effective March 9, 2010.

\section{Topographic and Bathymetric Data}

All topographic data used in this study are referenced vertically to NAVD 88 and horizontally to the North American Datum of 1983 (NAD 83). Cross-section elevation data were obtained from a digital elevation model (DEM) that was derived from light detection and ranging (lidar) data that were collected as part of a statewide project during 2011-13 by Woolpert, Inc. (2011). The lidar data for Shelby County were collected in 2013. The DEM was obtained from the Indiana Spatial Data Portal (Indiana University, 2013). The original lidar data have horizontal resolution of $4.9 \mathrm{ft}$ and vertical accuracy of $0.98 \mathrm{ft}$ at a 95 -percent confidence level based on a root mean squared error of $0.49 \mathrm{ft}$ for the "open terrain" land-cover category. By these criteria, the lidar data support production of 2-ft contours (Dewberry, 2012); the final DEM, which was resampled to a grid-cell size of $10 \mathrm{ft}$ by $10 \mathrm{ft}$ to decrease the GIS processing time, has a vertical accuracy of plus or minus $1 \mathrm{ft}$. By using HEC-GeoRAS (a set of procedures, tools, and utilities for processing geospatial data in ArcGIS), elevation data were extracted from the DEM for 36 cross sections. These data subsequently were input to the HEC-RAS model.

Because lidar data cannot provide ground elevations below a stream's water surface, channel cross sections were surveyed by USGS field crews during September 2015.

Cross-sectional depths were measured by using hydroacoustic instrumentation at 20 locations. A differential global positioning system (DGPS) with real-time kinematic (RTK) technology was used to derive horizontal locations and the elevation of the water surface at each surveyed cross section.

In the ArcMap application of ArcGIS (Esri, 2014), these field data were used in conjunction with a bathymetry mesh tool, created by Merwade and others (2008), to interpolate below-water ground elevations through the study reach. The density of ground elevations in the mesh was determined by two variables: (1) the number of parallel longitudinal profiles that were evenly spaced across the channel and ran the length of the study reach and (2) the user-specified spacing between cross sections. Ground elevations were either extracted or interpolated from the field data at the intersections of the longitudinal profiles and cross sections that were spaced approximately $500 \mathrm{ft}$ apart. The mesh elevations were subsequently added to the DEM data of the synthetic cross sections before the data were exported to HEC-RAS. Instructions for the bathymetry mesh tool are presented by Merwade (2011).

\section{Hydraulic Structures}

Three structures, consisting of two road crossings (Noble Street and State Road 9) and a railroad bridge, have the potential to affect water-surface elevations during floods along the river. Bridge-geometry data were obtained from field surveys conducted by personnel from the USGS Indiana-Kentucky Water Science Center. There are discontinuous earthen embankments along the river on the south bank. Because of the uncertainty as to the effectiveness of these embankments, 
they were not simulated as levees in the HEC-RAS model; rather, where appropriate to do so, the landward sides of the embankments were simulated as ineffective flow area up to the elevation of the top of the levee.

\section{Energy-Loss Factors}

Hydraulic analyses require the estimation of energy losses that result from frictional resistance exerted by a channel on flow. These energy losses are quantified by the Manning's roughness coefficient ( $n$-value) (Arcement and Schneider, 1989). Initial (pre-calibration) $n$-values were selected on the basis of field observations and high-resolution aerial photographs. An $n$-value of 0.03 was selected for the main channel because it is natural, fairly clean, and low gradient. An $n$-value of 0.08 was used for the overbank areas, which are dominated by agricultural fields and forest in the rural sections of the study reach, and the residential and commercial areas of Shelbyville both north and south of the river.

The initial $n$-values were adjusted as part of the calibration process, which involved minimizing the differences between simulated and observed water-surface elevations at the streamgage and elsewhere along the study reach. Roughness-coefficient adjustment factors were varied by flow and adjusted until the simulated water-surface elevations approximated the target water-surface elevations. The actual $n$-values were computed by multiplying the initial $n$-value by each of the roughness-coefficient adjustment factors. Main channel $n$-values ranged from 0.026 to 0.039 , and overbank values ranged from 0.074 to 0.100 .

\section{Hydraulic Model}

The HEC-RAS analysis for this study was done by using the steady-state flow computation option. Steady-state flow data consisted of flow regime, boundary conditions, and peak flows that produced water-surface elevations at the streamgage cross sections that matched target water-surface elevations within $0.24 \mathrm{ft}$ of the current rating for streamgage 03361500 . These target elevations coincided with even 1-ft increments of stage, referenced to the local streamgage datum. Subcritical (tranquil) flow regime was assumed for the simulations. Normal depth, based on an estimated average channel slope of 0.0004 from data obtained from Indiana DNR historic profiles and the channel slope at the downstream end of the study reach, was used as the downstream boundary condition of the reach. The peak flows that were used in the model are discussed in the "Hydrologic Data" section.

The hydraulic model was calibrated to the most current stage-discharge relation at the Big Blue River streamgage. Model calibration was accomplished by adjusting Manning's $n$-values until the results of the hydraulic computations closely agreed with the observed water-surface elevations for given flows. Differences between target and simulated water-surface elevations for the 12 simulated flows at the USGS streamgage were equal to or less than $0.24 \mathrm{ft}$ (table 4). The results demonstrate that the model is capable of simulating accurate water levels over a wide range of flows in the study reach. The datasets and model input used in this study are available through a data release at https://dx.doi.org/10.5066/F7WH2N48 (Fowler, 2017).

Table 4. Calibration of hydraulic model to target water-surface elevations at the U.S. Geological Survey streamgage on the Big Blue River at Shelbyville, Indiana (station number 03361500).

[NAVD 88, North American Vertical Datum of 1988]

\begin{tabular}{cccc}
\hline $\begin{array}{c}\text { Stage of water- } \\
\text { surface profile } \\
\text { (in feet) }\end{array}$ & $\begin{array}{c}\text { Target water- } \\
\text { surface } \\
\text { elevation (in } \\
\text { feet, NAVD 88) }\end{array}$ & $\begin{array}{c}\text { Simulated water- } \\
\text { surface elevation } \\
\text { (in feet, NAVD 88) }\end{array}$ & $\begin{array}{c}\text { Elevation } \\
\text { difference } \\
\text { (in feet) }\end{array}$ \\
\hline 9.00 & 746.21 & 746.37 & 0.16 \\
\hline 10.00 & 747.21 & 747.31 & 0.10 \\
\hline 11.00 & 748.21 & 748.35 & 0.14 \\
\hline 12.00 & 749.21 & 749.33 & 0.12 \\
\hline 13.00 & 750.21 & 750.22 & 0.01 \\
\hline 14.00 & 751.21 & 751.25 & 0.04 \\
\hline 15.00 & 752.21 & 752.30 & 0.09 \\
\hline 16.00 & 753.21 & 753.03 & -0.18 \\
\hline 17.00 & 754.21 & 753.97 & -0.24 \\
\hline 18.00 & 755.21 & 755.31 & 0.10 \\
\hline 19.00 & 756.21 & 756.29 & 0.08 \\
\hline 19.40 & 756.61 & 756.71 & 0.10 \\
\hline
\end{tabular}

\section{Development of Water-Surface Profiles}

The calibrated hydraulic model was used to generate water-surface profiles for a total of 11 stages at 1-ft intervals between $9 \mathrm{ft}$ and $19 \mathrm{ft}$ and 1 stage at $19.4 \mathrm{ft}$ as referenced to the local datum of the Big Blue River streamgage. These stages correspond to elevations between $746.21 \mathrm{ft}$ and $756.61 \mathrm{ft}$, NAVD 88.

\section{Development of Flood-Inundation Maps}

Flood-inundation maps were created in a GIS for the 12 water-surface profiles by combining the profiles and digital elevation model data. The DEM data were derived from the same lidar data described previously in the "Topographic and Bathymetric Data" section and therefore have an estimated vertical accuracy of $2 \mathrm{ft}$ (that is, plus or minus $1 \mathrm{ft}$ ). Estimated flood-inundation boundaries for each simulated profile were developed with HEC-GeoRAS software (U.S. Army Corps of Engineers, 2011), which allows the preparation of geometric data for import into HEC-RAS and processes simulation results exported from HEC-RAS (U.S. Army Corps of Engineers, 2010). Shapefile polygons and depth grids of the inundated areas for each profile were modified, as required, in 
the ArcMap application of ArcGIS to ensure a hydraulically reasonable transition of the flood boundaries between modeled cross sections.

Any inundated areas that were detached from the main channel were examined to identify subsurface connections with the main river, such as through culverts under roadways. Where such connections existed, the mapped inundated areas were retained in their respective flood maps; otherwise, the erroneously delineated parts of the flood extent were deleted. The flood-inundation areas are overlaid on high-resolution, geo-referenced, aerial photographs of the study area. Bridge surfaces are displayed as inundated regardless of the actual water-surface elevation in relation to the lowest structural chord of the bridge or the bridge deck.

Estimates of water depth can be obtained from the depthgrid data that are included with the presentation of the flood maps on an interactive USGS mapping application described in the following section, "Flood-Inundation Map Delivery." The flood-inundation map corresponding to the highest simulated water-surface profile, a stage of $19.4 \mathrm{ft}$, is presented in figure 2 .

\section{Flood-Inundation Map Delivery}

The current study documentation is available online at the USGS Publications Warehouse (https://pubs.er.usgs.gov/ publication/sir20165166). Also, a Flood Inundation Mapping Science Web site (U.S. Geological Survey, 2014b) has been established to make USGS flood-inundation study information available to the public; that site links to a mapping application that presents map libraries and provides detailed information on flood extents and depths for modeled sites. The mapping application enables the production of customized flood-inundation maps from the map library for the Big Blue River at Shelbyville, Ind. A link on this Web site connects to the USGS NWIS (U.S. Geological Survey, 2014c), which presents the current stage and streamflow at USGS streamgage 03361500 to which the flood-inundation maps are referenced. A second link connects to the NWS AHPS site (National Weather Service, 2014c) so that the user can obtain applicable information on forecasted peak stage. The estimated flood-inundation maps are displayed in sufficient detail so that preparations for flooding and decisions for emergency response can be performed efficiently. Depending on the flood magnitude, roadways are shown as shaded (inundated and likely impassable) or not shaded (dry and passable) to facilitate emergency planning and use. Bridges are shaded - that is, shown as inundatedregardless of the flood magnitude. A shaded building should not be interpreted to indicate that the structure is completely submerged, rather that bare earth surfaces in the vicinity of the building are inundated. In these instances, the water depth (as indicated in the mapping application by holding the cursor over an inundated area) near the building would be an estimate of the water level inside the structure, unless flood-proofing measures had been implemented.

\section{Disclaimer for Flood-Inundation Maps}

The flood-inundation maps should not be used for navigation, regulatory, permitting, or other legal purposes. The USGS provides these maps "as is" for a quick reference, emergency planning tool but assumes no legal liability or responsibility resulting from the use of this information.

\section{Uncertainties and Limitations Regarding Use of Flood-Inundation Maps}

Although the flood-inundation maps represent the boundaries of inundated areas with a distinct line, some uncertainty is associated with these maps. The flood boundaries shown were estimated on the basis of water stages and streamflows at a selected USGS streamgage. Water-surface elevations along the stream reaches were estimated by steady-state hydraulic modeling, assuming unobstructed flow, and using streamflows and hydrologic conditions anticipated at the USGS streamgage. The hydraulic model reflects the land-cover characteristics and any bridge, embankment, or other hydraulic structures existing as of September 2015. Unique meteorological factors (timing and distribution of precipitation) may cause actual streamflows along the modeled reach to vary from those assumed during a flood, which may lead to deviations in the water-surface elevations and inundation boundaries shown. Additional areas may be flooded because of unanticipated conditions such as changes in the streambed elevation or roughness, backwater into major tributaries along a main stem river, blockage of water due to earthen embankments, or backwater from localized debris or ice jams. The accuracy of the floodwater extent portrayed on these maps will vary with the accuracy of the DEM used to simulate the land surface.

If this series of flood-inundation maps will be used in conjunction with NWS river forecasts, the user should be aware of additional uncertainties that may be inherent or factored into NWS forecast procedures. The NWS uses forecast models to estimate the quantity and timing of water flowing through selected stream reaches in the United States. These forecast models (1) estimate the amount of runoff generated by precipitation and snowmelt, (2) simulate the movement of floodwater as it proceeds downstream, and (3) predict the flow and stage (and water-surface elevation) for the stream at a given location (AHPS forecast point) throughout the forecast period (every 6 hours and 3 to 5 days in the future in many locations). For more information on AHPS forecasts, please refer to https://water.weather.gov/ahps/forecasts.php.

Other sources of uncertainty are the model discharges and water-surface elevations on the Big Blue River upstream of Little Blue River. The drainage area on the Big Blue River is approximately 25 percent less than downstream of the confluence with the Little Blue River and the streamgage. Thus, there is some uncertainty in the discharge upstream of the confluence during each flood event in the upper reach of the hydraulic model. 


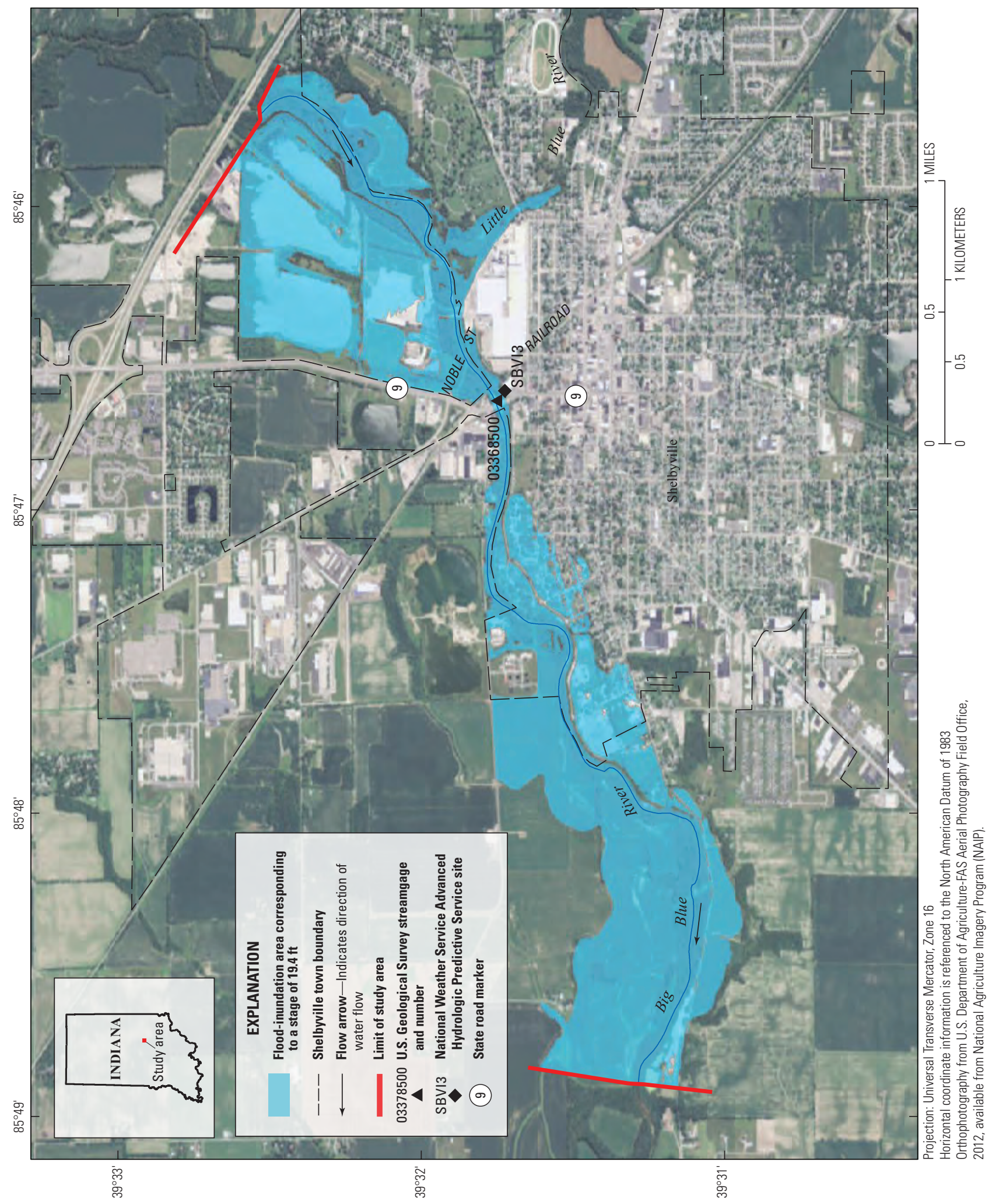

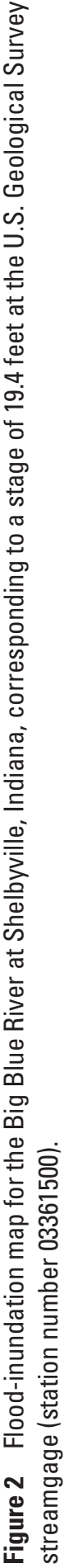




\section{Summary}

A series of 12 digital flood-inundation maps were developed in cooperation with the Indiana Office of Community and Rural Affairs for the Big Blue River at Shelbyville, Indiana, from $1.47 \mathrm{mi}$ upstream to $2.63 \mathrm{mi}$ downstream from U.S. Geological Survey (USGS) streamgage 03361500 at the State Road 9 bridge. The maps were developed by using the U.S. Army Corps of Engineers' HEC-RAS and HEC-GeoRAS programs to compute water-surface profiles and to delineate estimated flood-inundation areas and depths of flooding for selected stream stages. The HEC-RAS hydraulic model was calibrated to the current stage-discharge relation at the Big Blue River streamgage at Shelbyville (03361500). The model was used to compute 12 water-surface profiles for flood stages referenced to the streamgage datum and ranging from $9 \mathrm{ft}$, or near bankfull, to $19.4 \mathrm{ft}$, which is the highest stage of the stage-discharge rating. The simulated water-surface profiles were then combined with a Geographic Information System digital elevation model derived from light detection and ranging (lidar) data to delineate estimated flood-inundation areas as shapefile polygons and depth grids for each profile. These flood-inundation polygons were overlaid on high-resolution, geo-referenced, aerial photographs of the study area. The flood maps are available through a mapping application that can be accessed on the USGS Flood Inundation Mapping Science Web site (https://water.usgs.gov/osw/flood inundation).

Interactive use of the maps on the USGS mapping application can give users a general indication of depth of water at any point by using the mouse cursor to click within the shaded areas. The mapping application enables the production of customized flood-inundation maps from the map library for the Big Blue River at Shelbyville, Ind. These maps, in conjunction with the real-time stage data from the USGS streamgage, Big Blue River at Shelbyville, Ind. (station number 03361500), and forecasted flood stage data from the National Weather Service Advanced Hydrologic Prediction Service will help to guide the general public in taking individual safety precautions and will provide emergency management personnel with a tool to efficiently manage emergency flood operations and post-flood recovery efforts.

\section{References Cited}

Arcement, G.J., and Schneider, V.R., 1989, Guide for selecting Manning's roughness coefficients for natural channels and flood plains: U.S. Geological Survey Water-Supply Paper $2339,38 \mathrm{p}$.

Dewberry, 2012, National enhanced elevation assessment: Fairfax, Va., Dewberry, 84 p., accessed July 2014 at http:// www.dewberry.com/services/geospatial/national-enhancedelevation-assessment.
Esri, 2014, ArcGIS: Esri, accessed July 2014, at http://www. esri.com/software/arcgis/.

Federal Emergency Management Agency, 2006, Flood insurance study, Shelby County, Indiana, and unincorporated areas: Washington, D.C., Federal Emergency Management Agency, 29 p., 10 pls.

Federal Emergency Management Agency, 1981, Flood Insurance Study - City of Shelbyville, Indiana, Shelby County: Washington D.C., Federal Emergency Management Agency, $17 \mathrm{p}$.

Fowler, K.K., 2017, Big Blue River at Shelbyville, Indiana, flood-inundation geospatial datasets: U.S. Geological Survey data release, https://doi.org/10.5066/F7WH2N48.

Gray, H.H., 2000, Physiographic divisions of Indiana: Bloomington, Ind., Indiana Geological Survey Special Report 61, $15 \mathrm{p} ., 1 \mathrm{pl}$.

Indiana Department of Natural Resources, 2004, Digital flood insurance rate maps for Shelby County - Interim digital FIRMs: Indiana Department of Natural Resources, accessed November 2015 at http://www.in.gov/dnr/water/6594.htm.

Indiana Department of Natural Resources, 2014, Coordinated discharges of selected streams in Indiana: Indiana Department of Natural Resources, accessed January 2015 at http:// www.in.gov/dnr/water/4898.htm.

Indiana University, 2013, Indiana spatial data portal: Indiana University database, accessed March 2015 at http://gis. iu.edu/.

Merwade, Venkatesh, 2011, Creating river bathymetry mesh from cross-sections: Purdue University, School of Civil Engineering, 7 p., accessed March 2013 at http://web.ics. purdue.edu/ vmerwade/research/bathymetry_tutorial.pdf.

Merwade, Venkatesh; Cook, Aaron; and Coonrod, Julie, 2008, GIS techniques for creating river terrain models for hydrodynamic modeling and flood inundation mapping: Environmental Modelling and Software, v. 23, no. 10-11, p. 1300-1311.

National Weather Service, 2014a, Big Blue River at Shelbyville [Indiana] [SBVI3; USGS gaging station 03361500]: National Weather Service, Advanced Hydrologic Prediction Service, accessed December 2015 at http://water.weather.gov/ahps2/hydrograph. php?wfo=ind\&gage $=$ sbvi3 .

National Weather Service, 2014b, National Weather Service glossary-Action stage: National Weather Service, accessed June 2014 at http://w1.weather.gov/glossary/index. php?word=action+stage. 
U.S. Army Corps of Engineers, 2011, HEC-GeoRAS, GIS tools for support of HEC-RAS using ArcGIS-User's manual (ver. 43.93): U.S. Army Corps of Engineers, Hydrologic Engineering Center, [variously paged], accessed June 2014 at http:/www.hec.usace.army.mil/software/hec-georas/ documentation/HEC-GeoRAS_43_Users_Manual.pdf.

U.S. Army Corps of Engineers, 2010, HEC-RAS river analysis system-Hydraulic reference manual (ver. 4.1): U.S. Army Corps of Engineers, Hydrologic Engineering Center, [variously paged], accessed June 2014 at http://www.hec. usace.army.mil/software/hec-ras/documentation/HECRAS_4.1_Reference_Manual.pdf.

U.S. Census Bureau, 2010, 2010 Census interactive population search-IN-Shelbyville city: Washington, D.C., U.S. Census Bureau, accessed January 2016 at http://www.census. gov/2010census/popmap/ipmtext.php?fl=18:1869318.

U.S. Geological Survey, 2014a, Flood Inundation Mapping (FIM) Program: U.S. Geological Survey Web site, accessed March 2015 at http://water.usgs.gov/osw/flood_inundation.

U.S. Geological Survey, 2014b, StreamStats in Indiana: U.S. Geological Survey StreamStats Program, accessed April 2015 at http://streamstats.usgs.gov/indiana.html.
U.S. Geological Survey, 2014c, USGS 03361500 Big Blue River at Shelbyville, IN—Current/historical observations: U.S. Geological Survey National Water Information System, accessed December 2014 at http://nwis.waterdata.usgs. gov/in/nwis/uv?site_no $=03361500$.

U.S. Geological Survey, 2014d, USGS 03361500 Big Blue River at Shelbyville, IN—Peak streamflow: U.S. Geological Survey National Water Information System, accessed December 2014, at http://nwis.waterdata.usgs.gov/in/nwis/ peak? site_no $=03361500 \&$ agency_cd $=$ USGS\& format $=\mathrm{html}$.

U.S. Geological Survey, 2014e, USGS 03361500 Big Blue River at Shelbyville, IN - Summary of all available data: U.S. Geological Survey National Water Information System, accessed December 2014 at http://nwis.waterdata. usgs.gov/in/nwis/nwisman/?site_no=03361500\&agency_ $\mathrm{cd}=\mathrm{USGS}$.

Woolpert, Inc., 2011, Indiana statewide digital orthoimagery [metadata]: Indiana University, Woolpert Order No. 71177, prepared by Woolpert, Inc., Geospatial Services [Dayton, Ohio], accessed December 16, 2015, at http://gis.iu.edu/ files/documents/in2011_ortho.txt. 
Publishing support provided by the:

U.S. Geological Survey Science Publishing Network,

Denver, Madison, and Rolla Publishing Service Centers

For more information concerning the research in this report, contact:

Director, Indiana Water Science Center

U.S. Geological Survey

5957 Lakeside Boulevard, Indianapolis,

IN 46278-1996

https://in.water.usgs.gov/ 

